\title{
Vicriviroc Maleate
}

National Cancer Institute

\section{Source}

National Cancer Institute. Vicriviroc Maleate. NCI Thesaurus. Code C73146.

A maleate salt form of Vicriviroc, a piperazine-based CCR5 receptor antag onist with activity against human immunodeficiency virus. Vicriviroc is designed to bind to CCR5 and inhibit the entry of HIV into CD4 cells. 